A N N A L E S

UNIVERSITATIS MARIAE CURIE-SKŁODOW S A LUBLIN - POLONIA

VOL. LXXI, z. 2

SECTIO B

2016

Zakład Polityki Przestrzennej i Planowania, Wydział Nauk o Ziemi i Gospodarki Przestrzennej

Uniwersytet Marii Curie-Skłodowskiej

20-718 Lublin, al. Kraśnicka 2cd; wagw@poczta.umcs.lublin.pl

WALDEMAR A. GORZYM-WILKOWSKI

\title{
Planowanie przestrzenne jako czynnik kształtujący atrakcyjność rynkową nieruchomości \\ - skuteczny i niebezpieczny
}

Spatial planning as an efficacious and risky factor shaping

the market attractiveness of properties

Slow
zabudowy

Keywords: spatial planning, properties, local development, building dispertion

\section{WPROWADZENIE}

Większość funkcji życiowych człowieka, w tym także większość zadań realizowanych przez władze publiczne, wymaga użytkowania nieruchomości o określonych cechach fizycznych i prawnych. Zatem właściwe gospodarowanie w przestrzeni, a zwłaszcza gospodarowanie składnikami przestrzeni przez ludzi i instytucje, wymaga właściwej gospodarki nieruchomościami. Hopfer i Sobczak (1998) twierdzą, że gospodarka nieruchomościami jest jednym z wymiarów szerszego agregatu pojęciowego, jakim jest gospodarka przestrzenna. Oznaczać to musi, że pomiędzy gospodarką nieruchomościami a innymi aspektami gospodarki przestrzennej występują silne i wielorakie interakcje. Wydaje się, że szczególnie silne związki z gospodarowaniem nieruchomościami wykazuje planowanie przestrzenne, przy czym to właśnie planowanie przestrzenne, uwzględniając rzecz jasna strukturę nieruchomości, jest najczęściej czynnikiem sprawczym, oddziałującym na możliwości, charakter i kierunki gospodarki nieruchomościami (zob. np.: Ustawa z dnia 21 sierpnia 1997 r. o gospodarce nieruchomościami). Co wię- 
cej - to przez mechanizmy gospodarowania nieruchomościami dochodzą do skutku kluczowe efekty ekonomiczne i społeczne planowania przestrzennego.

Niniejszy tekst opiera się na hipotezie, iż wpływ planowania przestrzennego na wartość nieruchomości, a w efekcie także na lokalną przestrzeń społeczno-ekonomiczną, jest bardzo efektywny. Przy czym wpływ ten może mieć wiele pozytywnych, zróżnicowanych skutków, lecz jednocześnie może tworzyć równie liczne następstwa negatywne. Rodzi to pytanie o charakter i sposób planowania przestrzeni, który wzmacniałby skutki pozytywne, a jednocześnie eliminował lub ograniczał efekty negatywne.

Artykuł dotyczy zjawisk zachodzących w obecnej przestrzeni społeczno-ekonomicznej Polski. Został więc oparty na aktualnie obowiązującym ustawodawstwie dotyczącym planowania przestrzennego i gospodarki nieruchomościami, Jako obiekt badawczy został wybrany obszar województwa lubelskiego, z odniesieniami dotyczącymi innych części kraju.

\section{PRZESŁANKI}

W świetle ustawy Kodeks cywilny (1964) nieruchomością jest część powierzchni kuli ziemskiej stanowiąca odrębny przedmiot własności (grunt), jak również budynki trwale $\mathrm{z}$ gruntem związane lub części takich budynków. Nieruchomość jest jednym z głównych przedmiotów własności, czyli korzystania i pobierania pożytków oraz dochodów. Sposób wykonywania prawa własności nieruchomości kształtują, zgodnie z ustawą o planowaniu i zagospodarowaniu przestrzennym (2003), ustalenia miejscowego planu zagospodarowania przestrzennego. To zatem planowanie przestrzenne rzutuje, często w sposób rozstrzygający, na wartość i rynkową atrakcyjność poszczególnych nieruchomości. Plan miejscowy stanowi, dla potencjalnego nabywcy, źródło informacji dotyczących praw i ograniczeń w zagospodarowaniu i użytkowaniu określonej nieruchomości gruntowej oraz szans i zagrożeń, które mogą wystąpić w jej otoczeniu (zob. np.: Jędraszko 1996). Jest to zresztą zupełnie oczywiste, biorąc pod uwagę funkcję planu miejscowego jako podstawy wydawania pozwoleń na budowę. Wśród wymienionych przez ustawę o planowaniu przestrzennym kompetencji tego planu, cały szereg w bezpośredni lub pośredni sposób oddziałuje na to, w jaki sposób nieruchomość może być użytkowana i w efekcie - jakie może być spektrum potencjalnych jej nabywców. Miejscowy plan zagospodarowania przestrzennego określa np. dla poszczególnych terenów:

- przeznaczenie (dopuszczalną funkcję),

- zasady zagospodarowania, w tym zabudowy (dopuszczalną wysokość, intensywność, odległość od dróg itp.), a także ewentualny zakaz zabudowy,

- zasady ochrony ładu przestrzennego, walorów przyrodniczych i kulturowych, 
- sposoby i zasady wyposażenia w infrastrukturę techniczną,

- zasady scalania i podziałów.

Niektóre z tych rozstrzygnięć oddziałują na wartość nieruchomości w sposób bezpośredni. Oczywiste jest np., że ustalenie w planie miejscowym funkcji rokującej wyższą rentę gruntową (np. mieszkalnictwo lub usługi komercyjne) poprawia wartość nieruchomości, podczas gdy przeznaczenie tejże nieruchomości na cele m.in. zieleni publicznej wartość tę radykalnie zmniejsza. Podobnie zwiększa cenę terenu dopuszczenie większej intensywności jego zabudowy lub ustalenie podziału na względnie małe działki budowlane, a ogranicza ją np. wprowadzenie całkowitego zakazu zabudowy.

Nie bez znaczenia jest również pośredni wpływ planu miejscowego na wartość nieruchomości. Wynika on zwłaszcza z ustalonych w planie funkcji i zasad zagospodarowania terenów sąsiadujących lub w jakiś sposób funkcjonalnie powiązanych $\mathrm{z}$ daną nieruchomością. Pomiędzy sposobami wykorzystania sąsiadujących lub powiązanych nieruchomości występują bowiem liczne interakcje, z których część może mieć charakter pozytywny, część natomiast negatywny (np. prowadząc do konfliktów).

\section{KORZYŚCI}

Miejscowy plan zagospodarowania przestrzennego może, jak wspomniano powyżej, oddziaływać na wartość nieruchomości w sposób zarówno korzystny, jak i niekorzystny. Jednakże w dominującej części przypadków wpływ ten niewątpliwie jest korzystny. Wynika to przede wszystkim z mechanizmów prawnych zapisanych w ustawie o planowaniu i zagospodarowaniu przestrzennym. Procedura sporządzania planu miejscowego w zauważalny sposób uprzywilejowuje bowiem właścicieli nieruchomości, którzy mają liczne możliwości egzekwowania uwzględniania swoich interesów w przygotowywanych planach.

W efekcie, dominują obecnie plany miejscowe (lub zmiany tych planów) sporządzane zgodnie z oczekiwaniami właścicieli nieruchomości. Mechanizm ten sam w sobie nie jest naganny, przeciwnie - tworzy wiele pozytywnych zjawisk, których beneficjentami są liczni aktorzy lokalnej gospodarki. Wydaje się także zgodny z istotą planowania przestrzennego. Racją istnienia tej gałęzi planowania jest wszak poszukiwanie sposobów optymalnego wykorzystania przestrzeni. Optymalne wykorzystanie przestrzeni rozumiane jest natomiast jako takie, które generuje najwyższą wartość ekonomiczną (Zarządzanie przestrzenne... 2008). W tym kontekście można przyjąć, iż to właśnie właściciele nieruchomości dysponują najpełniejszą wiedzą co do ich walorów i możliwości wykorzystania. Zatem określenie przez plan miejscowy funkcji i sposobu zagospodarowania nieruchomości zgodnego z oczekiwaniami jej właściciela może być efektywnym sposobem osiągania koherencji lokalizacyjnej, będącej jednym z podstawowych 
celów gospodarowania przestrzenią (zob. np.: Zawadzki 1973; Budner 2003). Można to więc uznać za urzeczywistnienie ekonomicznego aspektu ładu przestrzennego, zakładającego zgodność lokalizacji i funkcji (zob.: Zawadzki 2001).

Pierwotnym beneficjentem odpowiednio sformułowanych ustaleń planu miejscowego są oczywiście właściciele nieruchomości, które w efekcie sporządzenia lub zmiany planu zyskują na wartości i atrakcyjności rynkowej (zob. np.: Raźniak, Grochal 2014). Różnica w rynkowej cenie nieruchomości rolniczych i budowlanych (mieszkaniowych lub usługowych) jest bowiem z reguły znaczna. Laskowska (2008) ocenia, że w realiach gmin podwarszawskich, będących terenem zjawisk suburbanizacyjnych, sięga ona 55\%. Są to różnice dotyczące transakcji, których przedmiotem są zawsze działki nabywane w celach budowlanych - zatem budowlane (w sensie funkcji w planie miejscowym) lub ,potencjalnie budowlane". W realiach województwa lubelskiego zatem, przy niższej przeciętnej sile nabywczej, różnice te są jeszcze większe. W gminach położonych bezpośrednio pod Lublinem grunty o ustalonej w planie miejscowym funkcji mieszkaniowej są droższe od położonych w tych samych miejscowościach gruntów o funkcji rolniczej o przynajmniej 35\%, na ogół o wyraźnie ponad 50\%, a w licznych przypadkach różnica sięga 200\% (www.anma.com.pl; www.kleczkowski.com.pl; www.lbn-nieruchomości.pl). Różnice cen transakcyjnych pomiędzy działkami budowlanymi a użytkami rolnymi nabywanymi w celach produkcji rolniczej są na Lubelszczyźnie jeszcze daleko większe, bo ponad 20-krotne (www.arimr.gov.pl).

Wzrost wartości rynkowej nieruchomości i będący tego efektem wzrost dochodów osób zbywających nieruchomości na cele inwestycyjne jest bezpośrednią korzyścią z planowania przestrzennego. W korzyści tej partycypuje także samorząd gminny. Zgodnie bowiem z ustawą o planowaniu i zagospodarowaniu przestrzennym osoba sprzedająca nieruchomość, której wartość wzrosła w efekcie sporządzenia lub zmiany planu miejscowego, ma obowiązek uiścić na rzecz gminy stosowną opłatę. Wysokość tej „opłaty planistycznej” może wynieść nawet $30 \%$ wzrostu wartości.

Oprócz bezpośrednich korzyści, wynikających z ingerencji planowania przestrzennego w wartość nieruchomości, istnieją liczne - być może jeszcze ważniejsze - korzyści pośrednie i odłożone w czasie. Wynikają one z sekwencji następstw ustalenia w planie miejscowym nowego przeznaczenia nieruchomości podnoszącego jej atrakcyjność inwestycyjną, a także z dominującego charakteru różnic pomiędzy przeznaczeniem uprzednim a określonym w planie. Typowym aktem planistycznym poprawiającym walory rynkowe nieruchomości jest przeznaczenie na cele mieszkaniowe lub usługowe nieruchomości wykorzystywanych dotychczas rolniczo. Zagospodarowanie tych nieruchomości zgodnie z planem oznacza wzrost wpływów podatkowych dla właściwej gminy. Od nieruchomości rolnych (bez rozróżnienia czy są zabudowane, czy też nie) właściciel płaci na rzecz gminy podatek rolny (Ustawa z dnia 15 listopada 1984 r. ...). Wysokość tego podatku jest 
aktualizowana corocznie, jednak jest on względnie niewielki. W roku 2016 podatek rolny płacony od $1 \mathrm{~m}^{2}$ gruntów wchodzących w skład gospodarstw rolnych wynosi tylko ok. 1,34 grosza, natomiast od pozostałych gruntów rolnych - ok. 2,69 grosza (Komunikat Prezesa GUS... 2015). Z kolei nieruchomości użytkowane w sposób niezwiązany z rolnictwem są podstawą, w świetle ustawy o podatkach i opłatach lokalnych (1991), uiszczania podatku od nieruchomości. Maksymalna wysokość tego podatku, różna dla nieruchomości gruntowych i dla budynków, jest również ustalana corocznie. Jest ona jednak zawsze wielokrotnie większa niż wysokość podatku rolnego. W roku 2016 najniższym pułapem podatku od $1 \mathrm{~m}^{2}$ nieruchomości gruntowych jest 47 groszy, natomiast od budynków - 75 groszy. Przy czym od budynków związanych z działalnością gospodarczą możliwe jest pobieranie nawet 22,86 złotych za $1 \mathrm{~m}^{2}$ (Obwieszczenie... 2015).

Zasadnicza różnica w wysokości podatku rolnego i podatku od nieruchomości powoduje, że ich skutki dla budżetów gminnych są zasadniczo odmienne. Tak np. w roku 2013 wpływy z podatku od nieruchomości stanowiły w województwie lubelskim ok. $26,90 \%$ dochodów własnych gmin, podczas gdy z podatku rolnego - jedynie ok. 8,9\% (Budżety jednostek... 2014). Działo się tak w województwie, w którym użytki rolne stanowią 70,1\% powierzchni, natomiast grunty zabudowane i zurbanizowane zaledwie 3,8\% (Województwo lubelskie..., 2015).

Podjęcie nierolniczego sposobu użytkowania nieruchomości wiąże się przy tym w licznych przypadkach z ich uprzednim zbywaniem na rzecz nowych właścicieli. Oznacza to napływ środków finansowych do dotychczasowych właścicieli nieruchomości. Wydawanie tych pieniędzy może przynajmniej w pewnym stopniu wzbudzić lokalny mnożnik konsumpcyjny, a zatem pobudzić przynajmniej niektóre sektory gospodarki lokalnej. Ponadto, środki uzyskane na sprzedaży nieruchomości stanowiących uprzednio np. część obszaru gospodarstwa rolnego mogą zostać zainwestowane w rozwój pozostałej części gospodarstwa rolnego lub w inne rodzaje działalności gospodarczej.

Efekty mnożnikowe mogą być oczywiście oparte na znacznie szerszych podstawach. Nabycie nieruchomości przez nowych właścicieli (nawet przez deweloperów) jest wszak wstępem do podjęcia inwestowania na tych nieruchomościach. Wydatki inwestycyjne związane z zagospodarowaniem nieruchomości (np. na materiały budowlane) ponoszone są generalnie poza obszarem inwestycji. Jednakże nawet stosunkowo niewielka część tych wydatków może mieć zauważalny wpływ na wzrost lokalnego popytu. Co więcej, nie wszystkie inwestycje muszą mieć w ostateczności charakter stricte konsumpcyjny. W istocie charakter ten mają prawie wyłącznie budynki mieszkalne. Natomiast inne przedsięwzięcia wykorzystujące racjonalizację (optymalizację) funkcji nieruchomości w planie miejscowym, na czele z usługowymi, mogą trwale poprawić sytuację ekonomiczną gminy i jej mieszkańców (por. np.: Parysek 2015). Beneficjentem tych korzyści 
są nie tylko lokalne przedsiębiorstwa i mieszkańcy, lecz także gmina. Zgodnie bowiem z ustawą o dochodach jednostek samorządu terytorialnego (2003) gminy partycypują $\mathrm{w}$ dochodach budżetu państwa $\mathrm{z}$ podatku dochodowego od osób fizycznych (na poziomie do 39,34\%) oraz od osób prawnych $(6,71 \%)$. W województwie lubelskim udziały w podatkach dochodowych stanowią podstawowy element dochodów własnych gmin - w roku 2013 wyniosły aż 36,1\% (Budżety jednostek... 2014). Zwiększenie dochodów gminy w oczywisty sposób musi poprawić jej możliwości inwestycyjne, które niewątpliwie w znacznej części będą wykorzystane na poprawę fizycznych cech lokalnych nieruchomości (przede wszystkim ich wyposażenie w infrastrukturę techniczną). To z kolei wpłynie na dalszą poprawę poziomu życia mieszkańców oraz warunki lokalizacji i funkcjonowania przedsiębiorstw. W licznych zatem przypadkach interwencja planowania przestrzennego w usytuowanie nieruchomości na rynku może stać się bodźcem uruchamiającym „maszynę wzrostu” (por.: Logan, Molotch 1987).

Z punktu widzenia władz gminy ustalanie w planie miejscowym funkcji i sposobu zagospodarowania nieruchomości w sposób zgodny z oczekiwaniami właścicieli niesie za sobą również inne korzyści, mianowicie polityczne. Właściciele nieruchomości są wszak także wyborcami, których głos może mieć znaczenie przy wyłanianiu np. nowego składu rady gminy. Mechanizm ten jest szczególnie istotny $\mathrm{w}$ gminach niebędących powiatami miejskimi. W gminach takich rady są wybierane w wyborach większościowych, w okręgach jednomandatowych, przy czy czym mandat zdobywa osoba, która otrzyma największą liczbę głosów, nawet jeśli nie jest to większość oddanych głosów (Ustawa z dnia 5 stycznia 2011 r. ...). Oznacza to, zwłaszcza w małych wiejskich gminach, gdzie do zdobycia mandatu wystarczy kilkadziesiąt głosów (http://wybory2014...; Obwieszczenie Komisarza...), silny związek pomiędzy radnym a wyborcami, a zatem także silną presję na decyzje radnych. Presja ta, oparta w dominującym stopniu na mechanizmach kontroli nieformalnej, skłania organy samorządu gminnego do działań zgodnych z oczekiwaniami mieszkańców jako warunku np. reelekcji (zob. np.: Szacka 2008).

\section{ZAGROŻENIA}

Zasadniczy, rozstrzygający mechanizm pozytywnego oddziaływania planowania przestrzennego na rynek nieruchomości i jego otoczenie wiąże się jednak z wieloma równoległymi niekorzystnymi następstwami. Presja właścicieli nieruchomości na poprawę jej wartości i rynkowej atrakcyjności powoduje w licznych przypadkach nadmierną podaż nieruchomości o cechach pożądanych na rynku. Śleszyński i in. (2015) wskazują, że pomimo pokrycia planami miejscowymi jedynie $28,6 \%$ terytorium Polski, możliwe jest zlokalizowanie na terenach prze- 
widzianych przez te plany na cele mieszkaniowe domów dla aż 79 mln osób. Są gminy, w których zgodnie z planami miejscowymi możliwe jest powstanie domów dla ludności ponad 10-krotnie liczniejszej niż aktualna liczba mieszkańców. W gminach tych bowiem plany miejscowe dopuszczają zabudowanie ponad połowy powierzchni (bez lasów i wód).

Takie, wielokrotnie przekraczające faktyczne potrzeby, a zwłaszcza realne możliwości inwestycyjne mieszkańców Polski, zakreślenie terenów o dopuszczalnej funkcji mieszkaniowej (niekiedy także usługowej) rodzi istotne negatywne następstwa. Przede wszystkim - zwłaszcza poza obszarami metropolitalnymi - realne ceny gruntów o ustalonej funkcji mieszkaniowej są znacznie niższe, niż oczekiwaliby ich aktualni właściciele. Przy tym, jedynie niewielka część właścicieli tych nieruchomości ma szanse ich zbycia i realnego osiągnięcia zakładanych przez siebie zysków. Samorządy gminne w takiej sytuacji również nie mogą liczyć na korzyści, nawet jeśli pojawią się krótkotrwałe zjawiska spekulacyjne. Ponadto, w praktyce polskie plany miejscowe nie ustalają sekwencji zagospodarowania przestrzennego, zatem kolejność zabudowywania poszczególnych terenów wskazanych w planie jest całkowicie przypadkowa. Mechanizm ten w oczywisty sposób musi prowadzić do daleko idącego rozproszenia zabudowy. Rozproszenie to zaś, oprócz np. uruchomienia nadmiernej antropopresji na tereny otwarte, ma również konkretne skutki ekonomiczne. Powoduje zwłaszcza nadmierne rozciągnięcie sieci dróg lokalnych oraz infrastruktury komunalnej. Szczególne koszty będą musiały ponosić gminy z racji konieczności wykupu gruntów przeznaczonych w planach miejscowych pod drogi (zob. np.: Raport... 2013). Jednak skutki nadmiernego rozproszenia zabudowy muszą powodować również długofalowe konsekwencje, w postaci wysokich kosztów utrzymania sieci infrastruktury komunalnej. Skutkiem tego będzie wysoki poziom wydatków bieżących kosztem ograniczenia wydatków rozwojowych (inwestycji).

Długotrwałą konsekwencją takiego zjawiska musi być ograniczenie możliwości rozwoju, poprawy warunków życia oraz lokalizowania i funkcjonowania przedsiębiorczości. Szczególnie odczuwalne będzie to być musiało w gminach położonych na obszarach depopulacyjnych, spośród których wiele posiada liczne obszary wskazane w planach miejscowych na cele mieszkaniowe. Na terenach tych koszt utrzymania sieci infrastruktury będzie się rozkładał na coraz mniejszą liczbę mieszkańców. W dłuższej perspektywie może to rodzić pytanie o wypłacalność gminy, a nawet o możliwość jej dalszego istnienia jako odrębnej jednostki samorządowej.

W obszarach metropolitalnych problem ten nie będzie zapewne równie istotny, choćby z uwagi na rosnącą liczbę mieszkańców i podmiotów gospodarczych, tworzącą korzyści opisane powyżej. Lecz tam również nadmierne rozproszenie 
zabudowy musi przynieść negatywne skutki, które będą się przede wszystkim wiązać $\mathrm{z}$ obciążeniem dziennego bilansu czasu wskutek rozciągnięcia dojazdów do pracy oraz pogorszeniem dostępności do podstawowych usług (zwłaszcza publicznych).

\section{WNIOSKI}

Planowanie przestrzenne, przez swoje oddziaływanie na wartość nieruchomości, tworzy wiele korzystnych zjawisk dla rozwoju lokalnego. Beneficjentami tych korzyści są bez mała wszyscy aktorzy lokalnej przestrzeni społeczno-ekonomicznej. Jednakże obok korzyści pojawiają się liczne zagrożenia. Przy czym zagrożenia te mogą w sposób trwały odbić się na kierunkach i tempie rozwoju gminy oraz możliwościach poprawy warunków życia jej mieszkańców. Powstaje zatem pytanie, w jaki sposób powinny zostać przekształcone powiązania pomiędzy planowaniem przestrzennym a gospodarką nieruchomościami, aby zachować lub wzmocnić skutki pozytywne, a jednoczenie wyeliminować lub ograniczyć efekty negatywne.

Podstawowym wyzwaniem jest ograniczenie ekspansji wyznaczanych przez plany miejscowe terenów mieszkaniowych, a nawet redukcja powierzchni i rozproszenie terenów już wyznaczonych. Wymaga to, jak się wydaje, zmiany systemu planowania przestrzennego. Zmiana taka niewątpliwie musiałaby się odbić dość boleśnie na funkcjonowaniu lokalnych rynków nieruchomości. Dla części podmiotów działających na tym rynku będzie bowiem oznaczać stratę lub przynajmniej pozbawienie nadziei na przyszłe korzyści. Jednakże straty w większości będą miały charakter doraźny $i$ indywidualny, związany np. z ograniczeniem możliwości tworzenia baniek spekulacyjnych. Natomiast otoczenie rynku nieruchomości i ich miejsce w rozwoju lokalnym uległyby zasadniczej racjonalizacji. Pozwoliłoby to znacznej większości zainteresowanych stron na bardziej realistyczne spojrzenie na możliwości odniesienia korzyści na rynku, a w efekcie także na podejmowanie mniejszej liczby nieracjonalnych decyzji. Samorządy gminne natomiast uzyskałyby niewątpliwie znaczne oszczędności w wydatkach na infrastrukturę komunalną. Jednakże systemowa korekta tych mechanizmów byłaby niewątpliwie bardzo trudna z racji oporu wielu podmiotów, zwłaszcza właścicieli nieruchomości. W takiej sytuacji szczególna odpowiedzialność spoczywa na władzach gmin, które powinny wykazywać większą świadomość interakcji pomiędzy planowaniem przestrzennym i rynkiem nieruchomości oraz ich następstwami. 


\section{SUMMARY}

A strong correlation occurs between spatial planning and the market attractiveness of properties. Since planning is a determinant of property value, the interests of participants of the property market have an impact on planning decisions. In consequence, local plans primarily specify the functions of areas according to the expectations of property owners so that it is possible to achieve a high land rent. This mechanism generates numerous positive effects for the entire local socio-economic space. Its beneficiaries include not only property owners but also local governments in districts and, to a certain extent, the entire environment. The adaptation of the provisions of local plans can be a trigger of lasting mechanisms ensuring local development. At the same time, however, it often leads to an excessive enlargement of residential areas in relation to the actual demand. This results in the increasingly scattered buildings. Besides the contamination of landscape, it also results in excessive costs of construction and maintenance of technical and road infrastructure. This can lead to a permanent limitation of the local government's ability to finance indispensable development projects. The excessive area of land for construction also creates a risk of speculation bubbles. Taking further advantage of the positive effects of links between spatial planning and property management as well as eliminating the negative effects probably requires a change in the system of planning in Poland. However, even under the current system, it is possible to achieve positive effects with an adequate level of knowledge and effective actions of the local government.

\section{LITERATURA}

Budner W., 2003: Lokalizacja przedsiębiorstw. Aspekty ekonomiczno-przestrzenne i środowiskowe, Wyd. Akademii Ekonomicznej w Poznaniu, Poznań.

Budżety jednostek samorządu terytorialnego w województwie lubelskim w 2013 r., 2014, Urząd Statystyczny w Lublinie, Lublin.

Hopfer A., Sobczak A., 1998: Gospodarka przestrzenna i gospodarka gruntami w Polsce. Zarys problematyki, [w:] A. Hopfer, Prawne i przestrzenne problemy gospodarowania nieruchomościami. Z doświadczeń polskich i zagranicznych, Biuletyn KPZK PAN, 183, 117-122.

Jędraszko A., 1996: Zarzadzanie mieszkalnictwem i planowanie komunikacji przez samorzad terytorialny w Niemczech, Unia Metropolii Polskich, Łódź.

Komunikat Prezesa GUS z dnia 20 października 2015 r. w sprawie średniej ceny skupu żyta za okres 11 kwartałów będącej podstawą do ustalenia podatku rolnego na rok podatkowy 2016, Monitor Polski 2015, poz. 1025.

Laskowska E., 2008: Zmiana przeznaczenia gruntu a jego wartość, Zeszyty Naukowe SGGW w Warszawie - Problemy Światowego Rolnictwa, 5 (20), 42-49.

Logan J., Molotch H., 1987: Urban Fortunes: The Political Economy of Place, University of California Press, Berkeley-Los Angeles.

Obwieszczenie Komisarza Wyborczego w Lublinie z dnia 21 listopada 2014 r. o wynikach wyborów do rad na obszarze województwa lubelskiego, Dz. Urz. Woj. Lub. 2014, poz. 4005.

Obwieszczenie Ministra Finansów z dnia 5 sierpnia 2015 r. w sprawie górnych granic stawek kwotowych podatków i opłat lokalnych w 2016 r., Monitor Polski 2015, poz. 735.

Parysek J. J., 2015: Rola lokalnego samorzadu terytorialnego w rozwoju społeczno-gospodarczym i przestrzennym gmin, Ruch Prawniczy, Ekonomiczny i Socjologiczny, LXXVII, 3.

Raport o ekonomicznych stratach i społecznych kosztach niekontrolowanej urbanizacji w Polsce, 2013, Fundacja Rozwoju Demokracji Lokalnej, Instytut Geografii i Przestrzennego Zagospodarowania PAN, Warszawa. 
Raźniak P., Grochal M., 2014: Wpływ zmiany miejscowych planów zagospodarowania przestrzennego na obrót nieruchomościami i ruch budowlany w gminie Dobczyce, [w:] Prace Naukowe Koła Naukowego Geografów Uniwersytetu Pedagogicznego w Krakowie, 1, 98-109.

Szacka B., 2008: Wprowadzenie do socjologii, Oficyna Naukowa, Warszawa.

Śleszyński P., Komornicki T., Deręgowska A., Zielińska B., 2015: Analiza stanu i uwarunkowań prac planistycznych w gminach w 2013 roku, Polska Akademia Nauk, Instytut Geografii i Przestrzennego Zagospodarowania, Warszawa.

Ustawa z dnia 23 kwietnia 1964 r. - Kodeks cywilny, t.j. Dz.U. 2016, poz. 380, z późn. zm.

Ustawa z dnia 15 listopada 1984 r. o podatku rolnym, t.j. Dz.U. 2013, poz. 1381, z późn. zm.

Ustawa z dnia 1991 r. o podatkach i opłatach lokalnych, t.j. Dz.U. 2014, poz. 849, z późn. zm.

Ustawa z dnia 21 sierpnia 1997 r. o gospodarce nieruchomościami, t.j. Dz.U. 2015, poz. 1774.

Ustawa z dnia 27 marca 2003 r. o planowaniu i zagospodarowaniu przestrzennym, t.j. Dz.U. 2015, poz. 199, z późn. zm.

Ustawa z dnia 13 listopada 2003 r. o dochodach jednostek samorządu terytorialnego, t.j. Dz.U. 2016, poz. 198.

Ustawa z dnia 5 stycznia 2011 r. - Kodeks wyborczy, Dz.U. 2011 nr 21, poz. 112, z późn. zm.

Województwo lubelskie. Statystyczne vademecum samorządowca, 2015, Urząd Statystyczny w Lublinie, Lublin.

Zarządzanie przestrzenne. Teoretyczne i praktyczne aspekty prognozowania finansowych skutków opracowań planistycznych, 2008, red. T. Bajerowski, Wyd. UWM, Olsztyn.

Zawadzki S. M., 1973: Polska, przestrzeń, społeczeństwo, PWE, Warszawa.

Zawadzki S. M., 2001: Ład przestrzenny, [w:] J. Kołodziejski, T. Parteka, Ksztaltowanie ładu przestrzennego polskich metropolii w procesie transformacji ustrojowej III RP, Biuletyn Komitetu Przestrzennego Zagospodarowania Kraju PAN, 193, 9-14.

\section{Źródla internetowe}

http://wybory2014.pkw.gov.pl/pl/wyniki/gminy/view/66401 [dostęp: 23.04.2016].

www.anma.com.pl/Oferty/Dzialki [dostęp: 17.04.2016].

www.arimr.gov.pl/dla-beneficjenta/srednie-ceny-gruntow-wg-gus.htlm [dostęp: 18.04.2016].

www.kleczkowski.com.pl/Oferty/Dzialki [dostęp: 17.04.2016].

www.lbn-nieruchomości.pl/Oferty/Dzialki [dostęp: 17.04.2016]. 